Global Business Research Congress, June 10-11, 2021

\title{
COVID 19 EFFECT ON THE TRANSFORMATION OF MARKETING
}

\author{
DOI: 10.17261/Pressacademia.2021.1418 \\ PAP- V.13-2021(7)-p.31-35
}

\section{Anil Serifsoy}

Isik University, Institute of Social Sciences, Istanbul, Turkey. anilserifsoy@gmail.com, ORCID: 0000-0002-7930-8045

To cite this document

Serifsoy, A. (2021). COVID 19 effect on the transformation of marketing. PressAcademia Procedia (PAP), V.13, 31-35.

Permanent link to this document: http://doi.org/10.17261/Pressacademia.2021.1418

Copyright: Published by PressAcademia and limited licensed re-use rights only.

\section{ABSTRACT}

Purpose- This paper aims to be an exploratory study that finds out the impacts of COVID-19 on marketing and enlightens further researchers on the topic.

Methodology-- Internet-based research will be conducted to collect the fundamental information on the impacts of COVID-19 on marketing as secondary data.

Findings- As a result of the research, As COVID-19 changed everything in our lives, consumer behavior has also changed which led to significant changes in marketing.

Conclusion- This article is one of the first steps to make further researcher on the change in the marketing especially after the COVID-19 eras.

Keywords: COVID 19, digital marketing, marketing 4.0, consumer behavior, prosumer

JEL codes: M10, M12, M19

\section{INTRODUCTION}

Since World War II, COVID-19 seems one of the biggest crises throughout the entire world. This crisis has affected all countries which let them have some precautions to protect their financial power. Even though all the countries are trying to protect themselves, the GDP worldwide has been affected. That is for sure made a immense impact on the buying behavior not only for the big companies but also for the individuals. Therefore it is not a surprise to see that an amazing change especially in marketing to find out different ways to attract the attention of the customer.

With this article, some important points related to consumer behavior and the need for companies to change their marketing strategies not only to adapt themselves to the present time but also for the future which will not be the same anymore.

\section{LITERATURE REVIEW}

Crises have had serious effects on people throughout history. Political crises, financial crises, and environmental crises are the most prominent ones that affect enourmous amounts of people. Financial crises have more power to spread out though out the entire globe in days, especially considering how the world has become such an interconnected place. The Credit Crisis of 1772, The Great Depression of 1929-1939, The Opec Oil Price Shock of 1973, The Asian Crisis of 1997, and finally the financial crisis of 2007 (Britannica, 2021 ) would be great examples for this

Depending on the type; the individual, social, organizational, and national effects and consequences of crises are displayed differently. Regardless of their type and consequences, crises always have a negative impact. Due to the changing economic, technological, social structure and developments with globalization, it causes devastating effects in large areas and also causes organizations and societies to encounter crises (Bulduklu \& Karaçor, 2017).

Infectious diseases and epidemics such as COVID-19, disasters, major accidents, unsuccessful medical practices, and problems are related to the functioning of the health system, which can be seen in all countries and cause a crisis in the health sector (Gül \& Çelebi, 2020). With the existence of COVID-19, the human health was the first thing that was affected. But in later stages, some other effects were seen in different areas as well. 
People that caught COVID-19 were affected health-wise. Some of them became ill, and unfortunately, there were quite a few casualties. But even if the rest of the population was not infected, it caused damage socially first, then psychologically, and finally economically. Therefore it became imperative for companies to change their strategies to protect their existence and provide resilience within their structure.

The companies should double-check and revise the way they have been acting for a long time, especially within the areas as shown below:
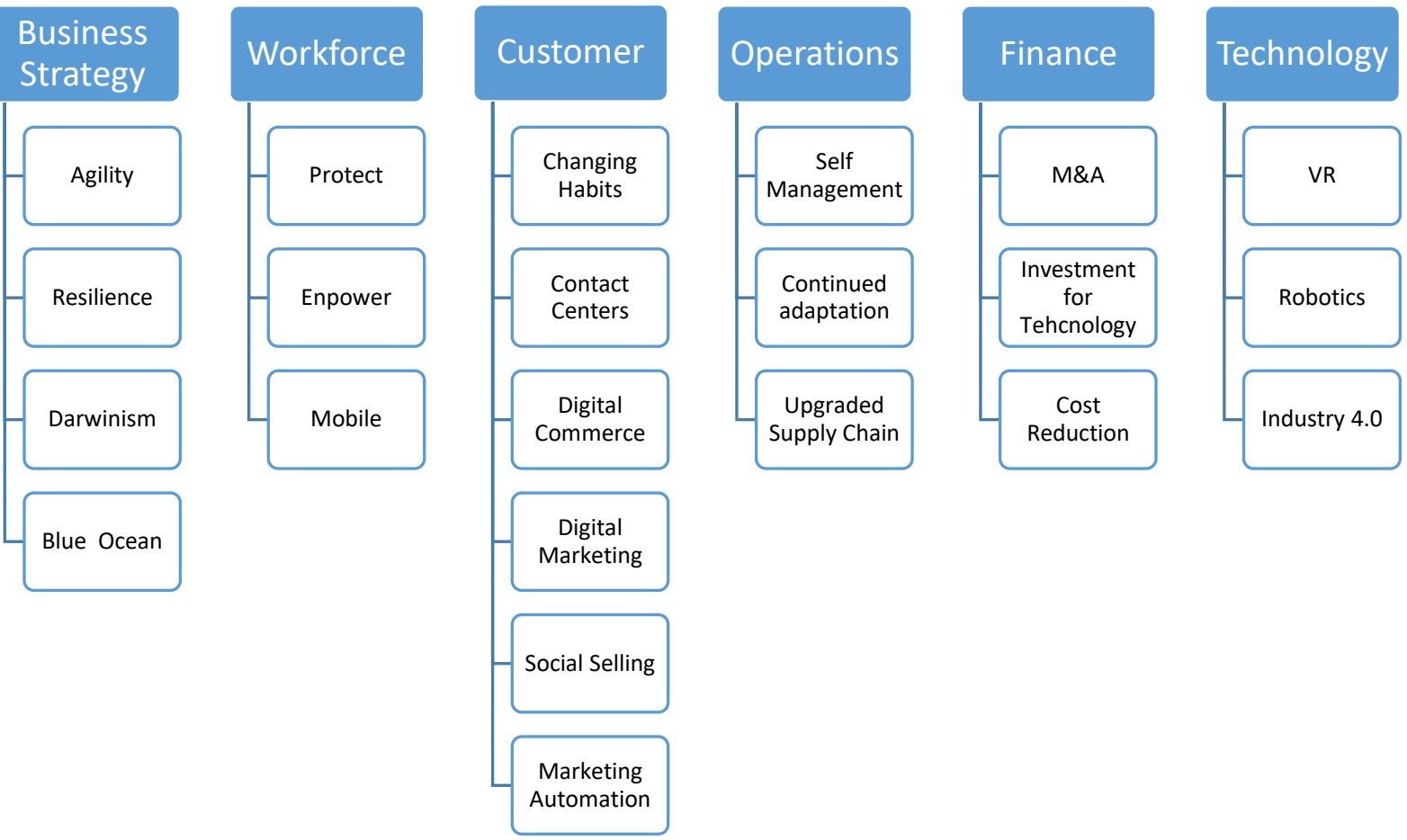

"As it is summarized within table 1 , these are major points and also the major challenges that need to be taken into consideration as actionable data by the managers and the CEOs of the companies and adapt their companies not only to thrive in the later stages of the COVID-19 and post COVID-19 era but also to maintain their existences at the forefront" (Şerifsoy, 2020).

As it is seen in table 1, all the companies should act more carefully when the subject is the customer. With the changing customer behavior and with the great difference in daily life, it became crucial for companies to take it into account. The concept of marketing has been changing with the change of buying behavior and other concepts as it is mentioned by Fuciu \& Dumitrescu "In the last three decades, the concept of marketing, as we can see, has changed by transforming into a managerial and social approach which considers the need to create a certain value for the consumers, for their community, and last but not in the least for the company." The change from marketing 1.0 to Marketing 4.0 is summarized in the following table. 


\section{Evolution of Marketing}

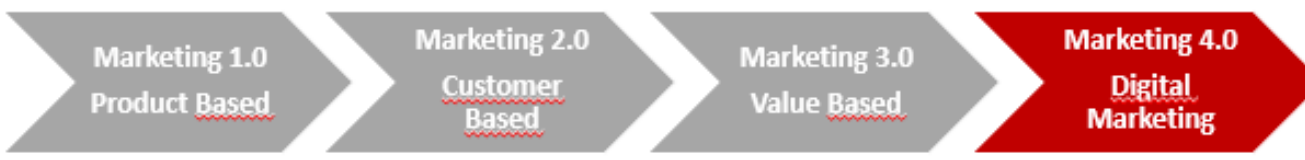

\begin{tabular}{|c|c|c|c|c|}
\hline \multirow[b]{2}{*}{ Concentration } & \multicolumn{3}{|c|}{ Traditional Marketing } & \multirow[b]{2}{*}{ Human Centered } \\
\hline & Praduct Oriented, Marketing & Consumer Oriented Marketing & Marketing Oriented towards people & \\
\hline Aim & Sale of praduct & Satisfaction and coustomer retertion & Making the world a better place & $\begin{array}{l}\text { Inspiring the client to co-create new } \\
\text { content and product }\end{array}$ \\
\hline $\begin{array}{l}\text { Forces enabling the } \\
\text { emergence of a cancept }\end{array}$ & Industrial revolution & Informatian technology & A new wave of technolagies & Digital econamy \\
\hline $\begin{array}{l}\text { The way companies } \\
\text { percieve the market }\end{array}$ & Mass customers with material needs & intelligent customers & A man with reason, heart and soul & Nitizen Man (Citizen of the network) \\
\hline Key Marketing Concept & Praduct develagement, & Diversification & Providing higher values & Anthropomorphization of brands \\
\hline Value proposition & Functional & $\begin{array}{l}\text { Functional } \\
\text { Emational }\end{array}$ & $\begin{array}{l}\text { Functianal } \\
\text { Emational } \\
\text { Spiritual }\end{array}$ & Commitment and trust \\
\hline $\begin{array}{l}\text { Interactions with } \\
\text { carsumer }\end{array}$ & One to manx & One ta one & Many to many & Networking \\
\hline
\end{tabular}

(Kotler, 2017)

With the latest changes in marketing, the human factor is positioned at the center and they are introduced as "nitizen" and "prosumers". These concepts have become more popular with the final effects of COVID 19 because it is surely the most important crisis that affects the entire globe in recent years. Some important concepts that affect consumer behavior shown below.

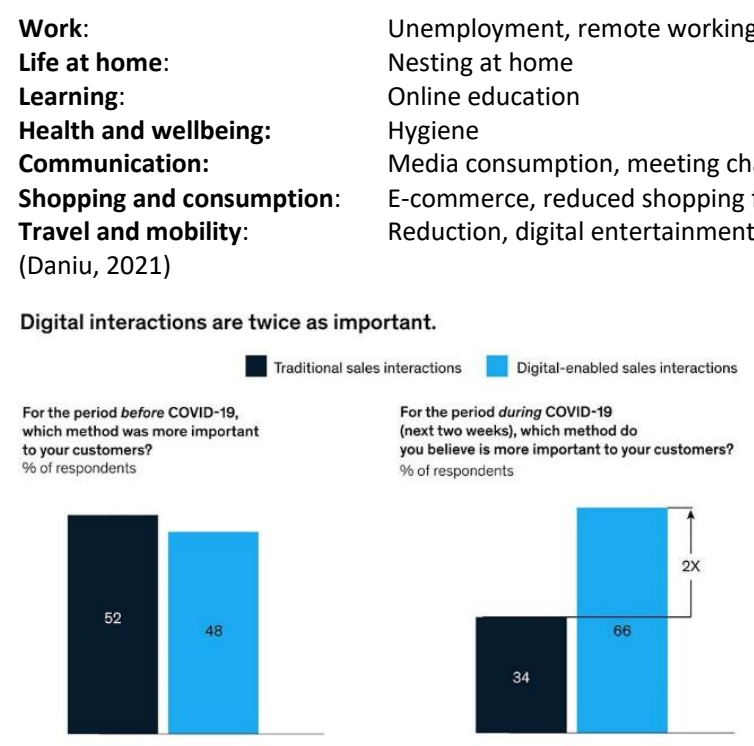

(McKinsey, 2020)

Digitalization is the key for the new marketing era as it is mentioned in Mckinsey's article about digital interactions. This is also visible in B2B marketing because it is central not only to keep up with innovation but also to increase the resilience level of companies to protect them from a potential crisis. Therefore all companies have started to revise their marketing budgets. According to Criteo, most of the companies have been focusing on different marketing activities and marketing channels to reach the target customers to provide interactions with them at the highest level. 

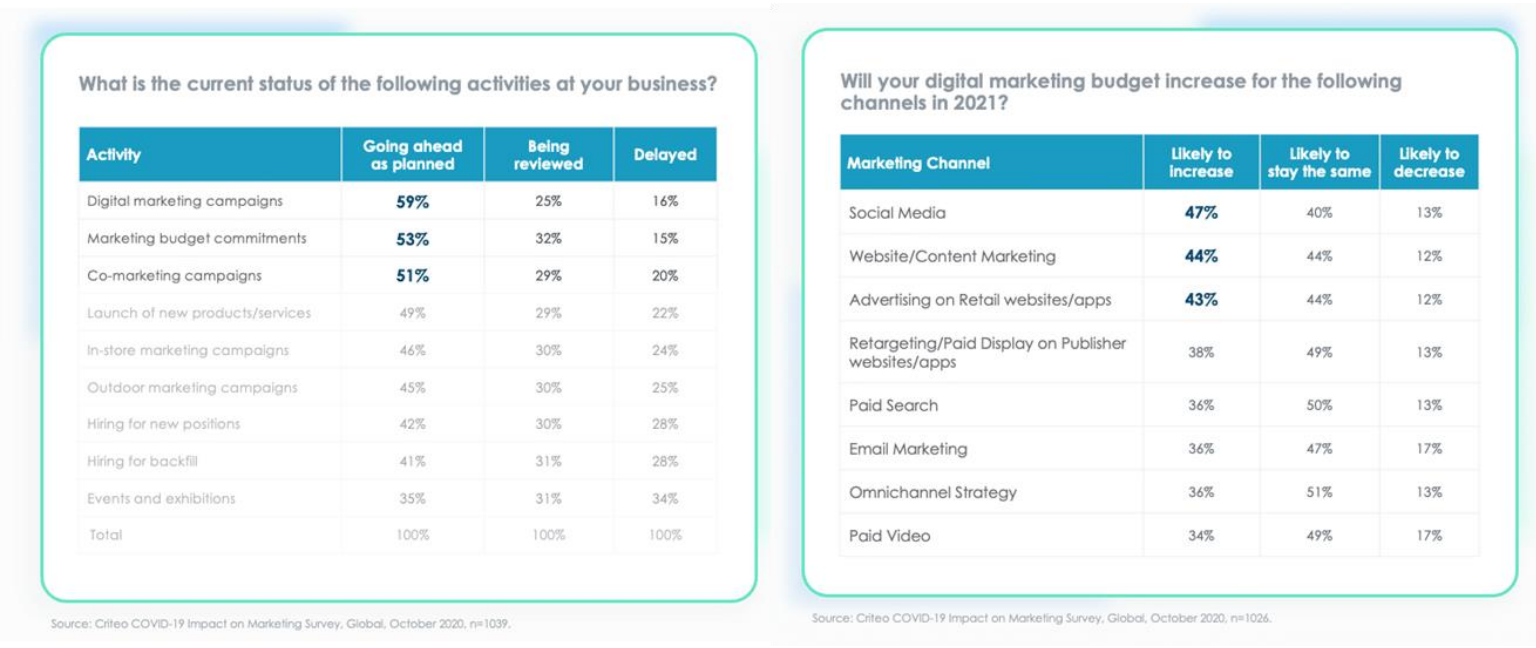

(Criteo, 2020)

The importance given to social media is revealed once again. Especially with the use of smartphones, access to social media has become much easier. With the number of active users increasing 4 times more than the world population growth, social media is becoming a part of our daily lives more and more every day. Social media comes to the forefront with its human-oriented approach, which is an indispensable part of marketing 4.0. In addition to social media, it is seen that virtual reality, which is the big technology in recent years, has gained a great deal of traction in marketing.

Through the pandemic, how has your organization interacted with customers?

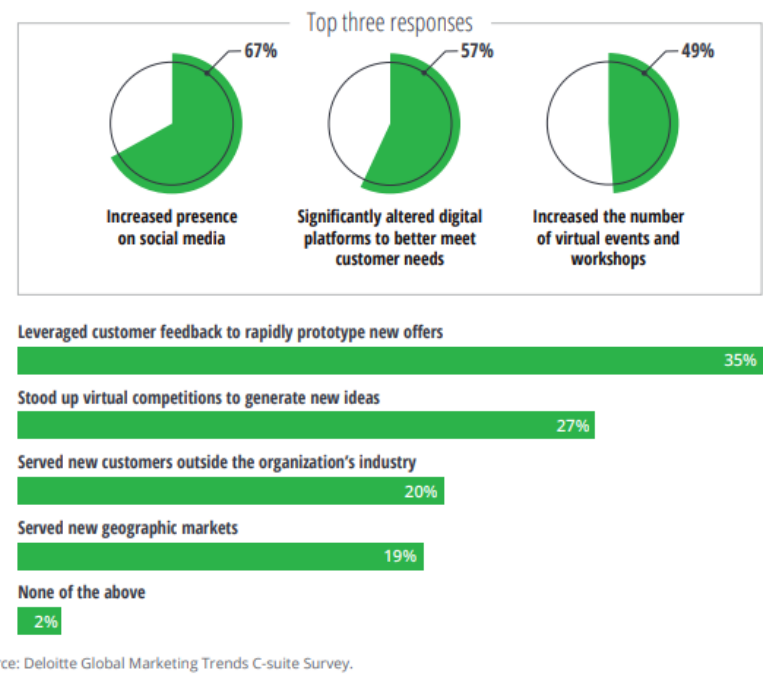

(Deloitte, 2021)

\section{DATA AND METHODOLOGY}

Secondary data is the way to access valuable information for this study. Background information related to the new marketing techniques is gathered with the review of the latest literature. The main reason behind writing this article is not only to show the change in marketing perception but also to inform companies about the changes and to help them to adapt to this new era in order to increase their chances of survival in the future, as well as warning them to prepare themselves to increase their resilience levels by making necessary preparations and budget allocations in accordance with innovations and the needs of the age.

Due to the dynamic and variable nature of marketing, the articles published in the period after the emergence of COVID-19 were examined and these reviews were associated with marketing 4.0 . 


\section{CONCLUSION}

Marketing has a variable structure as it depends on human psychology and behavior patterns. It has changed throughout history, especially with the effect of crises and technology changes, and will continue to change in line with the needs and requirements of the time period. Marketing 4.0, mentioned by Philip Kotler, has been on the agenda in recent years with the effect of digitalization, and with its humancentered focus. Companies have moved their relations with their customers to a different dimension and made the customer not only a consumer but also a productive consumer, "prosumers". With the effect of COVID-19, different channels of reaching customers were sought and revisions were made in the budgets for the diversity of these ways. An omnichannel strategy is applied rather than multichannel strategy. Today's marketing creates synergy with the strategy of involving the customer more and more in the processes. It is a matter of curiosity for us how the next focus of the new marketing perception, and how it will position the customer.

\section{REFERENCES}

Britannica. (2021). 5 of the World's Most Devastating Financial Crises. Retrieved from 5 of the World's Most Devastating Financial Crises: https://www.britannica.com/list/5-of-the-worlds-most-devastating-financial-crises

Bulduklu, Y., \& Karaçor, S. (2017). Crisis communication and new media in health services. Retrieved from CRISIS COMMUNICATION AND NEW MEDIA IN HEALTH SERVICES: https://dergipark.org.tr/tr/pub/atauniiletisim/issue/34005/357162

Criteo. (2020). COVID 19 Impact on Marketing Survey Global.

Daniu, V. (2021). Adapting and modernizing the Post-COVID marketing policy under the impact of consumption challenges. The Romanian Economic Journal.

Deloitte. (2021). Global Marketing Trends. C-suite Survey.

Fuciu, M., \& Dumitrescu, L. (2018). From marketing 1.0 to marketing 4.0 - the evolution of the marketing concept in the context of the 21 st century. International Conference, 45.

Gül, H., \& Çelebi, F. (2020). Evaluation of crisis management in the coronavirus (COVID-19) pandemic. Manas Journal of Social Studies. Retrieved from Evaluation of Crisis Management in the Coronavirus (COVID-19) Pandemic, the Major.

Kotler, P. (2017). Marketing 4.0 moving from traditional to digital. New Jersey: John Wiley \& Sons, Inc., Hoboken,.

McKinsey. (2020). B2B Decision Maker Pulse Survey.

Moorman, C. (2021). The CMO Survey. Retrieved from The Transformation of Marketing: Emerging Digital, Social and Political : https://cmosurvey.org/wp-content/uploads/2021/02/The_CMO_Survey-Highlights_and_Insights_Report-February-2021.pdf

Şerifsoy, A. (2020). Adaptation of the businesses not to fall behind in the new normaL. Journal of Management, Marketing and Logistics (JMML). 